\title{
IMPLEMENTASI SISTEM SAFETY DEVICE ENGINE OIL LEVEL PC 200-7 BERBASIS ARDUINO
}

\author{
Randis, Syaeful Akbar, Rony Darmawan \\ Jurusan Teknik Mesin, Program Studi Teknik Mesin Alat Berat \\ Politeknik Negeri balikpapan \\ Email: randis@poltekba.ac.id
}

\begin{abstract}
ABSTRAK
Penelitian ini merancang dan membuat suatu Safety device engine oil level yang akan diaplikasikan pada unit Komatsu PC 200-7. Sistem ini menggunakan engine oil level switch sebagai sensor untuk mengukur level oli pada oil pan. Operator dapat memperoleh informasi dari output LCD yang menampilkan text karakter dan buzzer sebagai indikator bunyi serta sistem ini juga mampu menonaktifkan starting sistem jika level oli mesin pada batas bawah (low). Pengujian alat dilakukan dengan mengurangi oli mesin sampai batas bawah (low), dan output dapat bekerja dengan baik. Begitu pula ketika dilakukan penambahan oli mesin sampai level diatas batas low, output dari sistem juga bekerja dengan sempurna. Pengujian dilakukan sebanyak 5 kali percobaan dan diperoleh hasil yang sesuai dengan standart pengujian alat yang diharapkan sehingga dapat disimpulkan bahwa alat ini dapat bekerja dengan baik.
\end{abstract}

Kata kunci: safety device, engine oil level, engine oil level switch

\begin{abstract}
This study designed and created safety oil engine level device that will be applied to Komatsu PC 200-7 unit. This system used an oil level switch engine as a sensor to measure oil level in oil pan. The operator can obtain information from the LCD output that displayed the character text and buzzer as a sound indicator and the system was also able to deactivate the starting system if the engine oil level was at the lower limit. Tool testing was done by reducing engine oil to the lower limit (low), andthe output can work well. Similarly, when adding engine oil to a level above the low limit, the output of the system also worked perfectly. Test was carried out as many as 5 experiments and the results obtained were in accordance with the standard expected testing tool, it can be concluded that this tool can work well.
\end{abstract}

Keywords: Safety device, engine oil level, engine oil level switch

\section{PENDAHULUAN}

Excavator PC200-7 merupakan pengembangan excavator hidraulik baru kelas menengah yang menyematkan berbagai konsep desain dan teknologi IT, sistem keamanan dan lingkungan. Unit ini memiliki luas kabin 14\% lebih besar dibandingkan versi pendahulunya, mesin didukung dengan pemasangan after cooler yang lebih besar sehingga emisi gas buang dapat diminimalisis hingga 32\%. Sistem keamanan juga ditingkatkan mulai dari kabin hingga mesin. Unit PC2007 telah dilengkapi dengan $L C D$ monitor yang memberikan beragam informasi melalui tampilan pada monitor tersebut, sehingga sangat cocok digunakan pada lokasi pertambangan di dunia 
tambang [1].

Engine merupakan komponen yang sangat penting pada excavator. Engine merupakan sumber tenaga bagi excavator untuk melakukan pekerjaan. Engine merubah energi panas yang dibangkitkan dari hasil pembakaran bahan bakar menjadi energi mekanik. Ketika engine mengalami trouble maka excavator dapat dikataan breakdown.

Salah satu sistem yang paling berperan dalam kinerja mesin yaitu sistem pelumasan. Sistem pelumasan pada mesin memegang peranan yang sangat vital dimana sistem pelumasan berfungsi sebagai mencegah kontak langsung antara dua permukaan yang saling bergesekan [2], untuk mengurangi panas yang terjadi pada sistem pelumasan akibat putaran tinggi pada engine [3]. Mencegah korosi dengan melapisi bagian mesin dengan lapisan pelindung yang mengandung adiktif untuk menetralkan bahan korosif [4]. Memperkecil koefisien gesek, pendingin (cooling), pembersih (cleaning), dan sebagai penyerap tegangan [5].

Sistem pelumasan pada engine harus ditunjang dengan kapasitas minyak pelumas yang tersedia pada oil pan, sehingga hampir semua unit kendaraan dilengkapi dengan dipstick oli untuk mengukur batas level oli, pada unit alat berat seperti PC 200-7 bahkan telah dilengkapi dengan sensor yang akan memberikan peringatan (caution lamp) di monitor panel untuk peringatan level oli jika telah berada pada batas low [1].

Pengembangan penelitian pada monitoring dan pendeteksian level permukaan tinggi cairan dengan berbagai perangkatnya menjadi sangat penting sehingga banyak telah banyak dilakukan untuk berbagai jenis aplikasi. Penelitian terdahulu telah mengungkapkan beberapa sensor dan peralatan yang digunakan untuk mengukur level liquid baik berupa cairan air ataupun cairan yang berbentuk minyak [6]-[12]. Sensor ultarsonic digunakan dalam [6]-[7], untuk mengukur tinggi bahan bakar pada generator dan sistem automotive, sementara Husni dkk. [8] juga memanfaatkan sensor ultrasonic dengan micro-controller arduino uno untuk mengukur volume suatu cairan dalam sebuah wadah. Goundar dkk. [9] menggunakan perangkat pressure sensor untuk mendeteksi ketinggian level bahan bakar, sedangkan Dongmei [10] menggunakan teknologi infrared image, bahkan penggunaan sensor terbaru pun telah dikembangkan untuk pengukuran dan monitoring level cairan [11][12].

Sistem yang akan dikembangkan berbeda dengan penelitian sebelumnya [6-12] yang menggunakan berbagai sensor yang sensitive dan tidak tahan terhadap getaran dan suhu extreme. Penggunaan sensor yang akan digunakan yaitu engine oil level switch, dimana sensor ini tahan terhadap getaran dan temperature tinggi sehingga sangat sesuai penggunaannya untuk kebutuhan unit alat berat yang dioperasikan pada daerah pertambangan.

Safety device engine oil level yang akan diaplikasikan pada unit Komatsu PC 200-7 ini dimaksudkan untuk mencegah operator yang seringkali mengabaikan lamp indikator peringatan oil level low pada unit, sehingga operator tidak akan mampu menghidupkan mesin jika oil level unit berada pada posisi low. Ketika kunci kontak pada posisi on, maka safety device mengeluarkan peringatan berupa bunyi buzzer dan juga text untuk mengecek level oli engine. Apabila engine di start, safety device ini akan memutuskan aliran listrik dari battery ke stater motor jika engine oil level pada posisi di bawah low.

\section{METODOLOGI PENELITIAN}

\section{Perancangan Sistem Elektrik Safety Device Engine Oil Level PC200-7}

Perancangan sistem elektrik dimaksudkan sebagai dasar dan acuan dalam imlementasi dan mempermudah dalam pembuatan alat. Blok diagram yang menujukkan rangkaian elektrik ditunjukkan dalam gambar 1. Blok diagram safety device engine oil level ini terdiri dari tiga bagian yaitu input, process, dan output. Input berupa power supply untuk memberikan power kepada mikrokontroller dan engine oil level switch yang berfungsi mengirimkan sinyal data ke 
arduino untuk diolah, sedangkan bagian process adalah arduino sebagai microkontroller yang merupakan tempat pemrosesan sinyal data dan informasi dari sensor. Output adalah relay yang berfungsi memutuskan dan menghubungkan starting system pada unit, kemudian buzzer yang akan mengeluarkan peringatan berupa suara dan $L C D$ yang akan menampilkan peringatan pada layar.

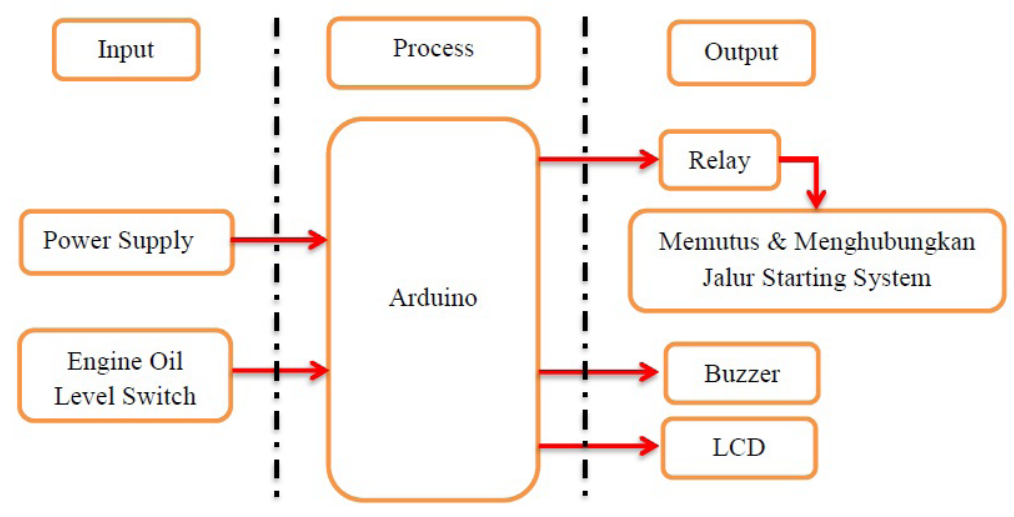

Gambar 1. Diagram Blok Sistem Elektrik Safety Device Engine Oil Level

\section{Perancangan Sistem Mekanik Safety Device Engine Oil Level PC200-7}

Perancangan sistem mekanikal menggambarkan penempatan alat pada unit excavator PC200-7 (gambar 2), alat ini terpasang pada kabin sehingga sangat memungkinkan operator mendengarkan indikator suara (buzzer) dan text dari $L C D$ ketika level oli berada pada batas bawah. Penempatan engine oil level switch diposisikan pada oil pan unit yang terhubung dengan alat melalui pengkabelan yang dihubungkan dengan terminal C starting switch.

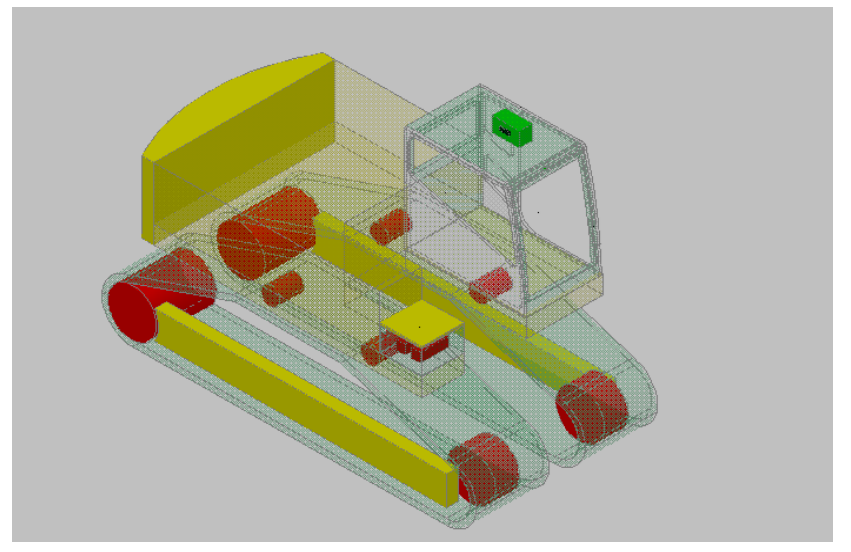

Gambar 2. Perancangan Sistem Mekanikal Safety Device Engine Oil Level

\section{Perancangan Schematic Diagram Sistem Safety Device Engine Oil Level PC200-7}

Skematic diagram safety device engine oil level menggambarkan skematik pemasangan power dari safety device engine oil level diambil dari starting switch terminal BR, lalu relay (NO) memutus dan menghubungkan arus dari starting switch terminal C ke motor stater. Kabel yang terhubung pada port 5 arduino dihubungkan ke jalur engine oil level switch yang akan menjadi input bagi alat. Skematic diagram safety device engine oil level ditunjukkan pada Gambar 3. 


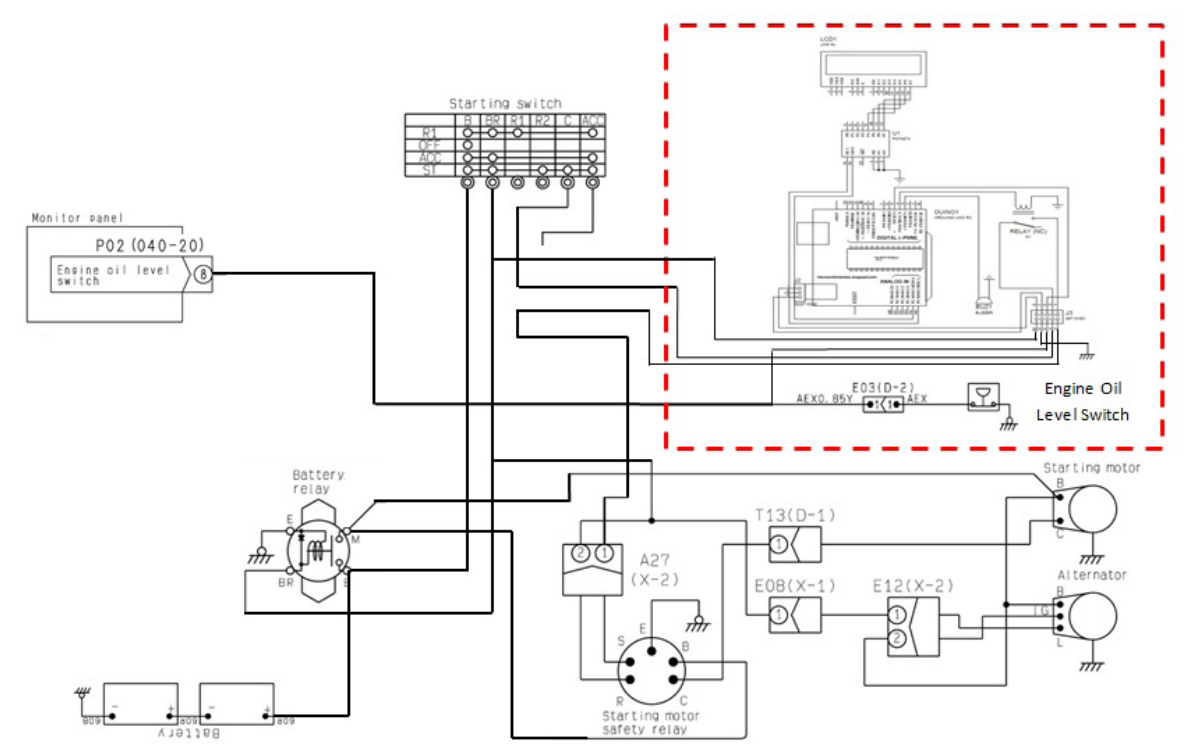

Gambar 3. Diagram Sistem Safety Device Engine Oil Level

\subsection{Diagram Alir Sistem Safety Device Engine Oil Level PC200-7}

Diagram alir sistem safety device engine oil level diperlihatkan pada gambar 4, ketika engine oil level switch mengirimkan signal kepada arduino bahwa engine oil level switch telah terhubung dengan ground (0 $\Omega)$, maka buzzer akan Off. LCD akan menampilkan tulisan "Can Start" dan Relay akan menghubungkan starting system. Ketika engine oil level switch mengirimkan signal bahwa engine oil level switch tidak terhubung dengan ground $(\infty \Omega)$, maka Buzzer akan $O N$, LCD akan menampilkan tulisan "Can't Start Oil Level : LOW' dan Relay akan memutuskan starting system.

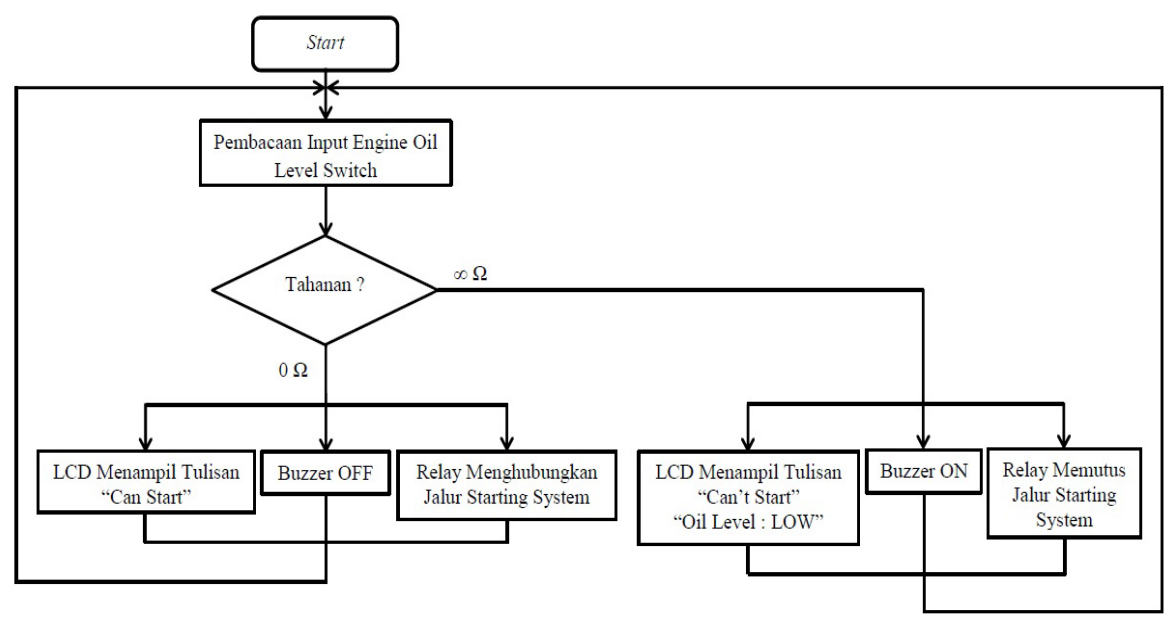

Gambar 4. Diagram Alir Sistem Safety Device Engine Oil

\section{HASIL DAN PEMBAHASAN}

\section{Implementasi Sistem Elektrik Safety Device Engine Oil Level PC200-7}

Pengembangan sistem ditunjukkan dalam diagram pengkabelan (Gambar 5) dan implementasi sistem (Gambar 6). Sistem ini terdiri dari 7 buah komponen elektronika yang 
dirangkai menjadi sebuah alat. Setiap komponen mempunyai fungsi dan kegunaan masingmasing. Engine oil level switch sebagai inputan dan arduino terhubung pada port 5 arduino, engine oil level switch merupakan alat yang digunakan untuk aplikasi populer dalam memantau tingkat antarmuka minyak-air [11]. Arduino sebagai microcontroller untuk memproses data sinyal input dari sensor. Mikrokontroller arduino cukup tangguh untuk dipogram dan dikembangkan, seperti pada penelitian yang dilakukan Chabni [13] dengan memadukan sistem fuzzy logic terintegrasi untuk mikrokontroller arduino.

Relay yang terhubung pada port 3 arduino sebagai output yang berfungsi memutus dan menghubungkan jalur starting terminal C starting switch dengan motor stater. Board sebagai tempat menghubungkan komponen satu sama lain. Buzzer berfungsi sebagai output yang terhubung pada port 4 Arduino yang akan mengeluarkan suara ketika engine oil level abnormal. Sistem ini dapat menampilkan karakter text pada $L C D$ seperti dalam [14] yang berfungsi sebagai output dari arduino. Sementara stepdown berfungsi menurunkan tegangan 24 volt menjadi 8 volt.

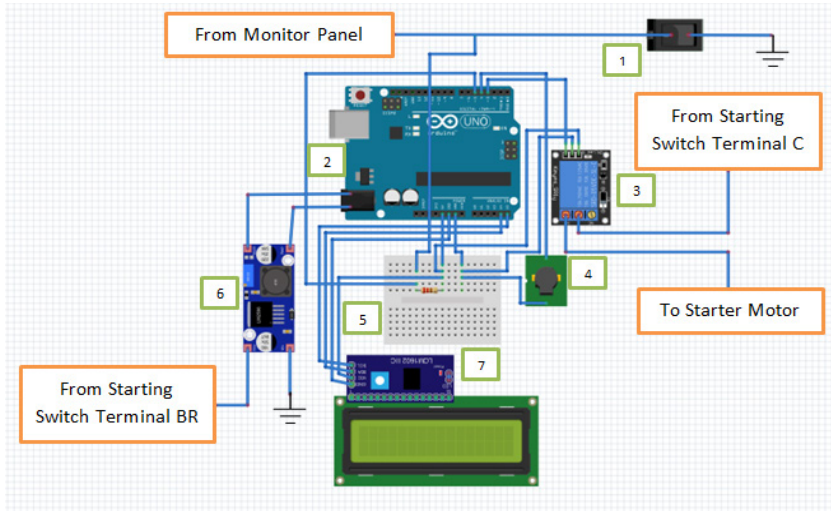

Gambar 5. Pengembangan Sistem elektrikal (Diagram Pengkabelan)

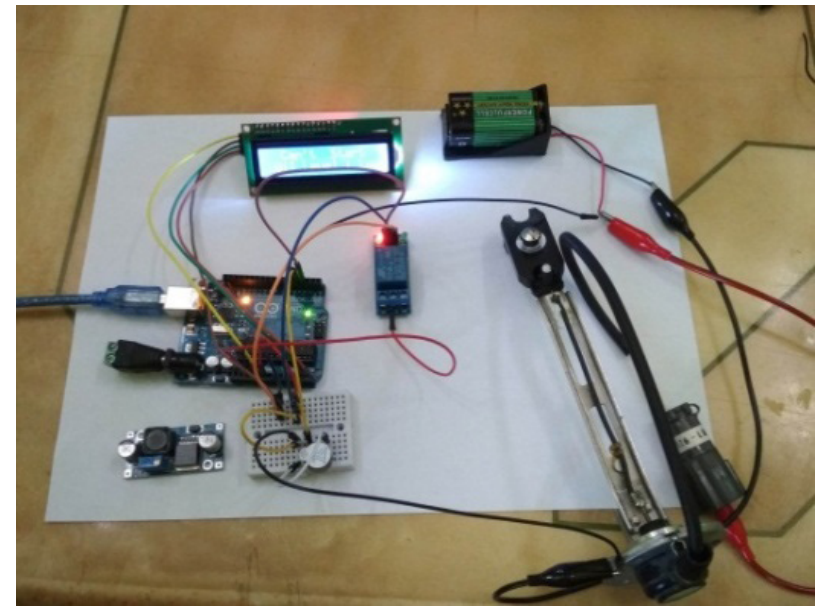

Gambar 6. Implementasi Sistem elektrikal

\subsection{Pemasangan Wiring Electric}

Pemasangan alat safety device diletakkan pada bagian kiri atas di dalam kabin sesuai dengan rancangan awal yang telah dibuat (Gambar 2). Alat safety device menggunakan box acrilik untuk menempatkan sejumlah komponen elektronik serta $L C D$ output text yang akan memberikan indikator kepada operator, alat ini dikait dengan 2 buah baut ukuran $8 \mathrm{~mm}$ yang sebagaimana ditunjukkan pada Gambar 7. 


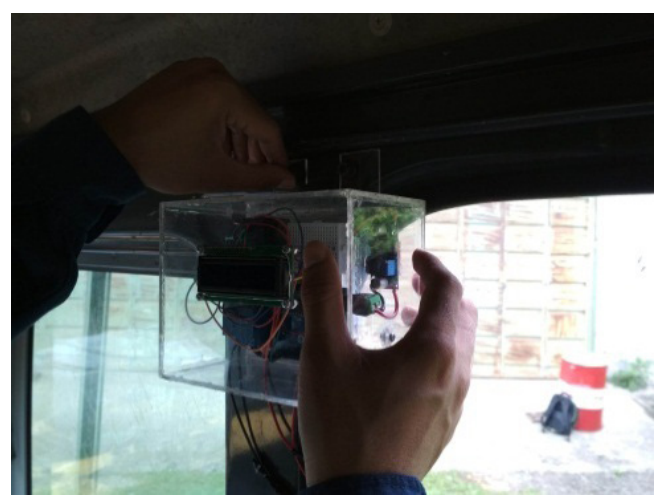

Gambar 7. Pemasangan Alat Safety Device

Pemasangan wiring didasarkan pada schematic diagram (Gambar 3) yang menggambarkan skematik pemasangan power dari safety device engine oil level diambil dari starting switch terminal BR, lalu relay (NO) memutus dan menghubungkan arus dari stating switch terminal $\mathrm{C}$ ke motor stater. Kabel yang terhubung pada port 5 arduino dihubungkan ke jalur engine oil level switch yang akan menjadi input bagi alat. Penyambungan kabel terminal $\mathrm{B}(+)$ safety device ke terminal C pada starting switch, kemudian kabel terminal $\mathrm{B}(-)$ safety device ke ground. Selanjutnya memutuskan kabel yang tersambung ke terminal C pada starting switch (Gambar 8) dan menyambungkan kabel terminal R1 safety device pada kabel yang telah diputus tadi dan menyambungkan kabel terminal R2 safety device pada terminal C starting switch. Yang terakhir menyambungkan kabel SO safety device ke jalur engine oil level switch seperti ditunjukkan pada Gambar 9.

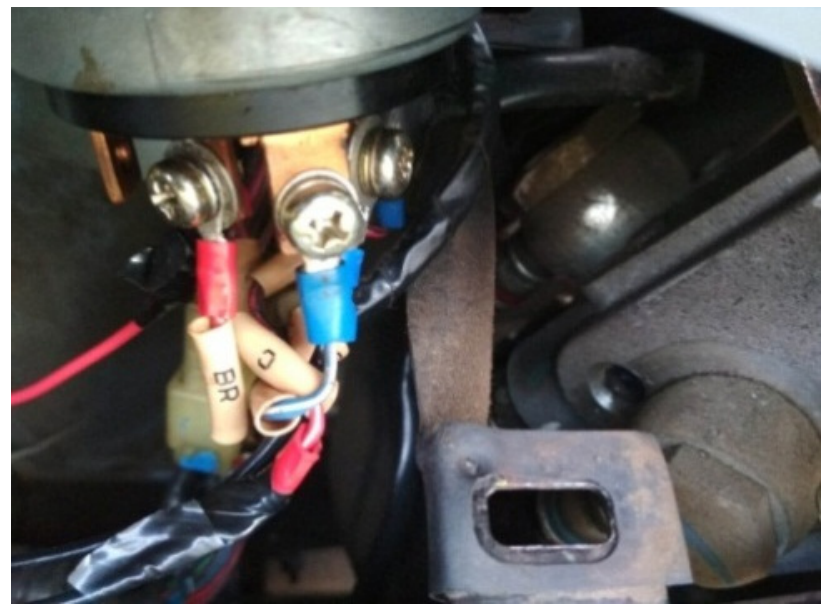

Gambar 8. Pemasangan Wiring Pada Starting Switch

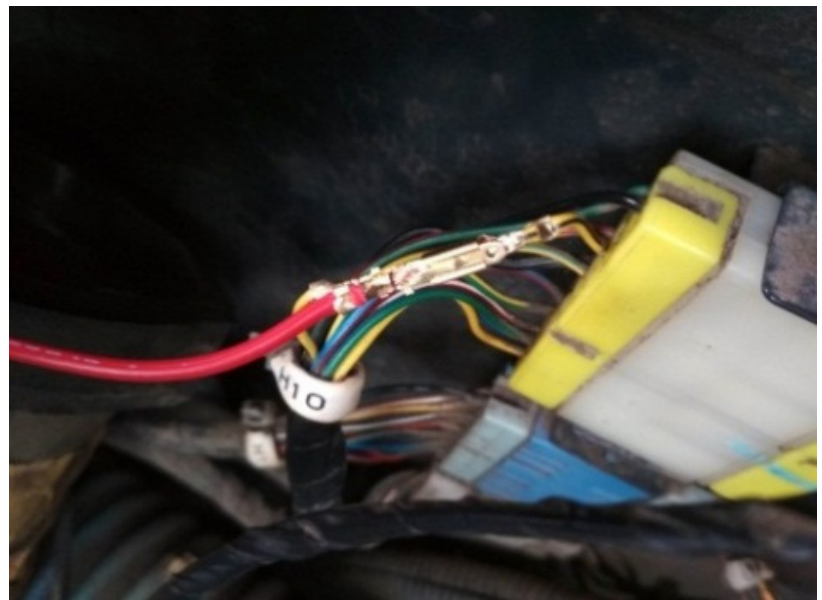

Gambar 9. Pemasangan Wiring Pada Jalur Engine Oil Level Switch

\section{Pengujian dengan Mengurangi dan Menambah Oli Engine}

Setelah wiring telah dipasang selanjutnya melakukan pengujian pada alat safety device oil engine level dengan mengurangi dan menambahkan oli pada oil pan. Pertama oli engine dikurangi terlebih dahulu sampai level oli engine pada dipstick berada di bawah low (Gambar 10). Setelah itu oli engine dikurangi sampai batas bawah (low) maka LCD akan mengeluarkan output pada safety device akan menampilkan tulisan "Engine Can't Start Oil Level: Low" yang berarti engine tidak dapat distart karena level oli engine kurang. Selain itu buzzer juga akan mengeluarkan bunyi dan relay memutuskan starting system. 


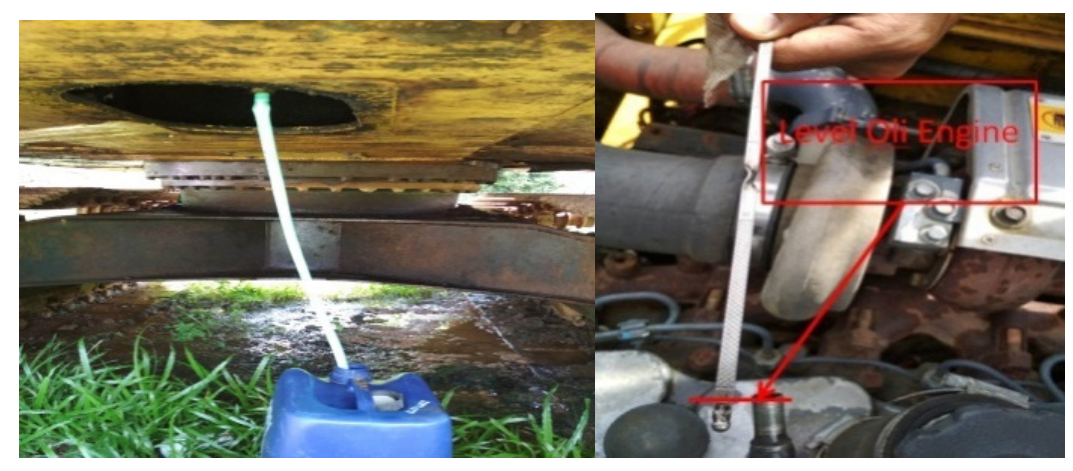

Gambar 10. Drain Engine Oil

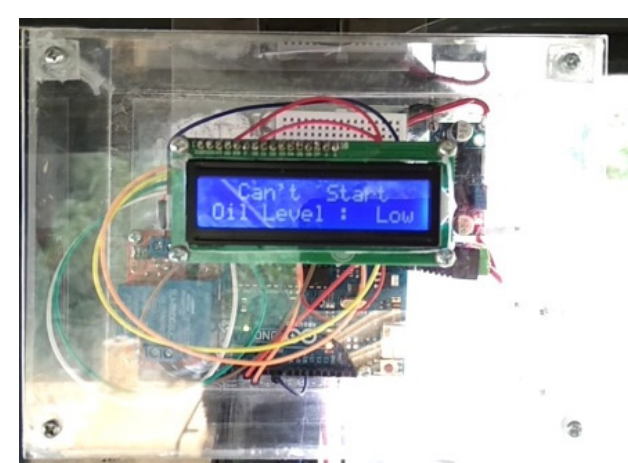

Gambar 11. Tampilan Safety Device Ketika Level Di Bawah Low

Setelah mengurangi oli engine dan melihat respon dari alat, selanjutnya menambahkan oli engine sampai level oli engine pada dipstick berada di atas low atau mencukupi seperti pada gambar 4.36. Kemudian seperti pada gambar 4.37 akan terlihat bahwa safety device akan menampilkan tulisan "Engine Can Start" yang berarti engine dapat distart. Selain itu buzzer akan off dan relay menghubungkan starting system.

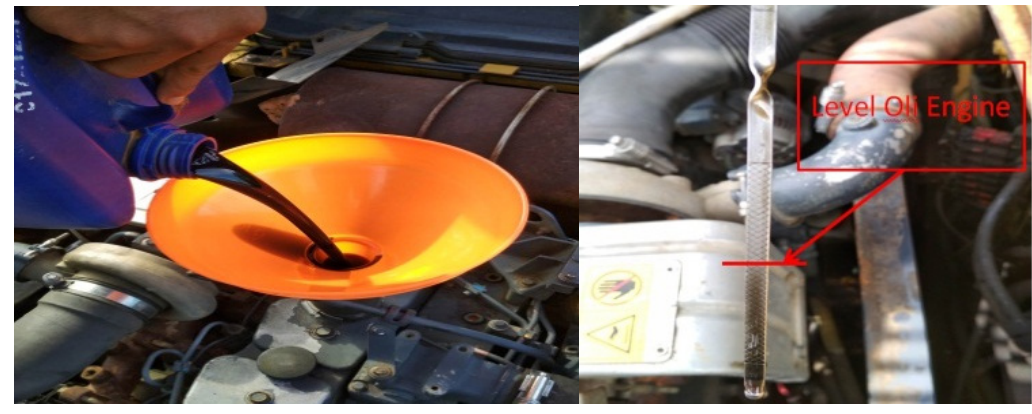

Gambar 12. Menambahkan Oli Engine

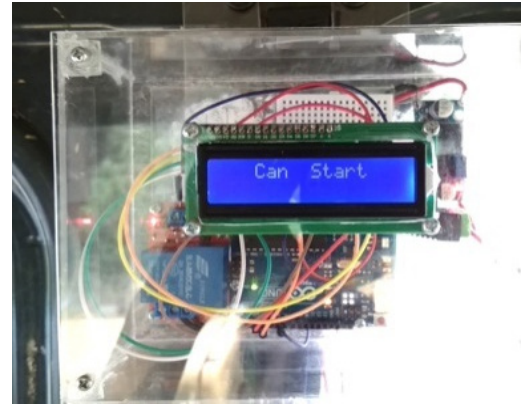

Gambar 13. Tampilan Safety Device Ketika Level Oli Mencukupi

\section{Pengujian Sistem Secara Keseluruhan}

Standart kerja alat yang terpasang pada unit $P C 200-7$ harus bekerja sesuai dengan ketentuan yang ditunjukkan pada tabel 1, ketika level oli mesin berada pada batas atas (diatas low) maka output berupa buzzer harus off sementara $L C D$ harus memberikan output pada layar dengan tulisan "Engine Can Start". Sementara relay pada posisi ON artinya mesin dapat di hidupkan karena relay yang digunakan yaitu relay dengan kontak NC (Normaly Close). Sedangkan ketika level oli mesin berada pada batas bawah (dibawah low), output buzzer harus on atau mengeluarkan indikator bunyi, dan layar LCD mengeluarkan output text "Engine Can't Start Oil Level: Low”.

Tabel 1. Standard Pengujian Alat

\begin{tabular}{lccc}
\hline \multicolumn{1}{c}{ Posisi Level Oli Engine } & Buzzer & Relay & LCD \\
\hline $\begin{array}{l}\text { Ketika level oli engine } \\
\text { mencukupi atau di atas low }\end{array}$ & OFF & ON & Engine Can Start \\
$\begin{array}{l}\text { Ketika level oli engine di } \\
\text { bawah low }\end{array}$ & ON & OFF & $\begin{array}{c}\text { Engine Can't Start } \\
\text { Oil Level: } \text { Low }\end{array}$ \\
\hline
\end{tabular}


Tabel 2. Hasil Pengujian Alat Ketika Level Oli Engine Mencukupi

\begin{tabular}{cccc}
\hline \multirow{2}{*}{$\begin{array}{c}\text { Percobaaan } \\
\text { Ke- }\end{array}$} & \multicolumn{3}{c}{ Ketika Level Oli Engine Mencukupi Atau Di atas Low } \\
\cline { 2 - 4 } & Buzzer & Relay & LCD \\
\hline 1 & OFF & ON & Engine Can Start \\
2 & OFF & ON & Engine Can Start \\
3 & OFF & ON & Engine Can Start \\
4 & $O F F$ & $O N$ & Engine Can Start \\
5 & $O F F$ & $O N$ & Engine Can Start \\
\hline
\end{tabular}

Tabel 3. Hasil Pengujian Alat Ketika Level Oli Engine Di Bawah Low

\begin{tabular}{|c|c|c|c|c|}
\hline \multirow{3}{*}{$\begin{array}{c}\begin{array}{c}\text { Percobaaan } \\
\text { Ke- }\end{array} \\
1\end{array}$} & \multicolumn{4}{|c|}{ Ketika Level Oli Engine Di Bawah Low } \\
\hline & \multirow{2}{*}{$\frac{\text { Buzzer }}{O N}$} & \multirow{2}{*}{$\frac{\text { Relay }}{O F F}$} & \multicolumn{2}{|c|}{ LCD } \\
\hline & & & Engine Can't Start & Oil Level: Low \\
\hline 2 & $O N$ & $O F F$ & Engine Can't Start & Oil Level: Low \\
\hline 3 & $O N$ & $O F F$ & Engine Can't Start & Oil Level: Low \\
\hline 4 & $O N$ & $O F F$ & Engine Can't Start & Oil Level: Low \\
\hline 5 & $O N$ & $O F F$ & Engine Can't Start & Oil Level: Low \\
\hline
\end{tabular}

Pengujian alat Safety device dilakukan sebanyak 5 kali untuk melihat hasil apakah alat tersebut dapat berfungsi dengan baik atau tidak. Berdasarkan hasil uji coba yang terlihat pada tabel 4.5 dan tabel 4.6 dibandingkan dengan standard pengujian pada tabel 4.4 dapat disimpulkan bahwa alat dapat berfungsi dengan baik sesuai dengan fungsinya, karena alat dapat bekerja sesuai dengan standard yang ditentukan (tabel 1).

\section{KESIMPULAN}

Sistem safety device engine oil level berhasil dibuat sesuai dengan perencanaan dan di aplikasikan serta di uji coba pada unit alat berat Komantsu Excavator PC200-7. Peringatan berupa text karakter sebagai indikator kepada operator dapat ditampikan pada layar $L C D$ serta peringatan bunyi dari buzzer. Sistem ini juga mampu menonaktifkan starting sistem jika level oli mesin pada batas bawah (low) sehingga operator harus menambahkan oli mesin untuk dapat menghidupkan unit, sehingga unit menjadi aman karena level oli mesin yang kurang akan sangat berpengaruh terhadap sistem pelumasan dan kinerja mesin unit secara keseluruhan.

\section{DAFTAR PUSTAKA}

[1] Y. Iwamoto, "Introduction of Products Introduction of Komatsu 's New Hydraulic Excavator PC200-7 in GALEO Series,” vol. 48, no. 149, 2002, pp. 35-44.

[2] Darmayanto, "Mengenal Pelumas Pada Mesin," Momentum, vol. 7, no. 1, pp. 5-10, 2011.

[3] E. Y. Widianto and H. Hartopo, "Analisis Terjadinya High Oil Consumption Pada Lubrucation System Pesawat Boeing 737-500 PK-GGF," INDEPT, vol. 6, no. 1, pp. 9-16, 2016.

[4] M. S. Effendi and R. Adawiyah, "Penurunan Nilai Kekentalan Akibat Pengaruh Kenaikan 
Temperatur Pada Beberapa Merek Minyak Pelumas,” Intekna, vol. 14, no. 1, pp. 92-101, 2014.

[5] T. P. M.Arisandi, Darmayanto, "Analisa Pengaruh Bahan Dasar Pelumas Terhadap Viskositas Pelumas dan Komsumsi Bahan Bakar," Momentum, vol. 8, no. 1, pp. 56-61, 2012 .

[6] D. Guatam, G. Modwel, A. Kumar, and A. Tiwari, "Fuel Level Management in Automotive System," Int. Confrence Green Comput. Internet Things, vol. 15, no. 2, pp. 1399-1401, 2015.

[7] T. Dhanya, "Real - Time Generator Fuel Level Measurement Meter With Ultrasound Sensor," Int. J. Mechnical Prod. Eng. Res. Develoment, vol. 8, no. 1, pp. 879-882, 2018.

[8] M. Husni, D. Siahaan, H. Ciptaningtyas, H. Studiawan, and Y. Aliarham, "Liquid volume monitoring based on ultrasonic sensor and Arduino microcontroller Liquid volume monitoring based on ultrasonic sensor and Arduino microcontroller," Int. Conf. Innov. Eng. Vocat. Educ., vol. 128, no. 1, pp. 1-10, 2016.

[9] J. A. Goundar et al., "Mechatronic Design Solution for Fuel Level Monitoring using Pressure Sensor," Comput. Sci. Eng. (APWC CSE), 2014 Asia-Pacific World Congr., vol. 1, no. 1, pp. 1-8, 2014.

[10] W. Dongmei, W. Ruyi, and L. Lihua, "Infrared Image Segmentation Technology," Int. Conf. Intell. Comput. Technol. Autom. Autom., vol. 4, no. 2, pp. 596-599, 2011.

[11] G. Lu, H. Hu, B. He, and S. Chen, “A New-type Sensor for Monitoring Oil-water Interface level and Oil Level," Int. Conf. Electron. Meas. Instruments, vol. 9, no. 2, pp. 981-983, 2009.

[12] A. M. Al-naamany, M. Meribout, K. Al Busaidi, and A. Concept, "Design and Implementation of a New Nonradioactive-Based Machine for Detecting Oil - Water Interfaces in Oil Tanks," IEEE Trans. Instrum. Meas., vol. 56, no. 5, pp. 1532-1536, 2007.

[13] F. Chabni, R. Taleb, A. Benbouali, and M. A. Bouthiba, "The Application of Fuzzy Control in Water Tank Level Using Arduino," Int. J. Adv. Comput. Sci. Appl., vol. 7, no. 4, pp. 261-265, 2016.

[14] A. Amin, "Monitoring Water Level Control Berbasis Arduino Uno Menggunakan LCD LM016L," J. EEICT, vol. 1, no. 2, pp. 41-52, 2018. 